\title{
Frequency of Anxiety Among Physicians Working in Emergency Departments and Other Clinics in Turkey: A Cross-Sectional Survey
}

\author{
Türkiye’de Acil Servis ve Diğer Kliniklerde Çalışan Doktorlarda Anksiyete \\ Sıklığı: Kesitsel Anket Çalışması
}

\author{
Mehmet KOCAK $\odot$, Osman Avsar GUL $\bullet$, Hakan AYDIN $\bullet$, Kurtulus ACIKSARI $\bullet$, \\ Dogac Niyazi OZUCELIK ๑
}

\begin{abstract}
Ethics Committee Approval: This study approved by the Bakirkoy Dr. Sadi Konuk Education and Research Hospital Clinical Studies Ethical Committee (11 April 2016, 2016/03/27). Conflict of interest: The authors declare that they have no conflict of interest. Funding: None.

Informed Consent: Informed consent was taken from all participants.

\section{ABSTRACT}

Objective: Physicians are exposed to various emotional and physical stressors in their working environment. Emergency departments are particularly stressful working environments. This study aimed to determine the frequency of anxiety among emergency physicians $(E P)$ and other medical specialists.

Methods: This cross-sectional survey included voluntarily participated physicians working in hospitals in Turkey. Physicians were grouped based on their Beck Anxiety Inventory (BAI) scores and their characteristics were compared. The frequency of anxiety and other characteristics of the physicians were investigated.

Results: $A$ total of 508 medical specialists (male $71.9 \%$; mean age $37.5 \pm 7.2$ years) included in the analysis, 97 (19.1\%) were EP and 411 (80.9\%) were from other medical specialties. The mean Beck Anxiety Inventory Score of the specialists from other clinics was 9.6 7.7 points. The frequencies of moderate, and severe anxiety among medical specialists were $13.8 \%$, and $2.8 \%$, respectively. The overall frequency of moderate-severe anxiety was $16.5 \%$; which was higher in emergency physicians than in other clinical specialists (33\% and $12.7 \%$, respectively). The mean Beck Anxiety Inventory scores of EP and other medical specialists were found as $13 \pm 9.3$ and $8.7 \pm 7.0$, respectively $(p<0.001)$. Anxiety score showed a negative correlation with age and duration of working as a specialist.Among emergency physicians, the rates of smoking ( $p=0.008)$, alcohol consumption $(p=0.003)$ and anxiety scores were higher and the duration of working as a specialist was shorter $(p<0.001)$.

Conclusions: Frequency of anxiety is higher among physicians. Considering medical specialties, higher level of anxiety determined in the emergency physicians might be a guide for investigation of working conditions in this field and for development of protective and preventive policies.
\end{abstract}

Cite as: Kocak M, Gul OA, Aydın H, Aciksari K, Ozucelik DN. Frequency of Anxiety Among Physicians Working in Emergency Departments and Other Clinics in Turkey: A Cross-Sectional Survey. Medeniyet Med J. 2019;34:135-42.
Keywords: Anxiety disorders, emergency physicians, Beck Anxiety Inventory

Öz

Amaç: Hekimler çalışma ortamlarında çeşitli duygusal ve fiziksel streslere maruz kalırlar. Acil servisler özellikle stresli çalışma ortamlarıdır. Bu çalışmada acil tıp uzmanlarında (ATU) ve diğer klinik uzmanlarında anksiyete sıklığının belirlenmesi amaçlanmıștır.

Yöntem: Türkiye'deki hastanelerde çalışan ve bu kesitsel anket çalışmasına gönüllü olarak katılmayı kabul eden uzman hekimler çalışmaya dahil edilmistir. Doktorlar, Beck anksiyete puanlarına göre gruplandırılmış ve özellikleri karşılaştırılmıştır. Hekimlerin anksiyete sıklığı ve diğer özellikleri incelenmiştir.

Bulgular: Analize dahil edilen 508 uzman doktorun (erkek: \%71,9; ortalama yaş: 37,5 $\pm 7,2$ ) 97'si $(\% 19,1)$ ATU, 411 'i $(\% 8,9)$ diğer klinik dallarda uzmandı. Beck anksiyete skorları ortalama

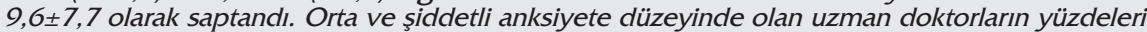
sırasıyla \%13,8 ve \%2,8 idi. Orta-şiddetli anksiyetesi olanların sıklığı \%16,5; bu oran ATU'larda diğer klinik uzmanlarınkinden daha yüksekti (sırasıyla \%33 ve \%12,7). ATU ve diğer klinik uzman doktorlarının ortalama Beck anksiyete düzeyleri sırasıyla $13 \pm 9,3$ ve $8,7 \pm 7,0$ olarak saptandı $(p<0,001)$. Anksiyete skoru yaş ve uzman olarak çalışma süresi ile negatif korelasyon gösterdi. Acil hekimlerinde sigara içme $(p=0,008)$ ve alkol tüketimi $(p=0,003)$ ile anksiyete skorları daha yüksek iken uzman olarak çalıșma süreleri daha kısaydı $(p<0,001)$.

Sonuç: Uzman doktorlarda anksiyete sıklığı yüksektir. Branşlar dikkate alındığında, acil tıp uzmanlarında saptanan yüksek anksiyete düzeyi, bu alandaki çalışma koşullarının araştırılması ve koruyucu ve önleyici politikaların geliştirilmesi için bir rehber olabilir.

Anahtar kelimeler: Anksiyete bozukluğu, acil, doktor, Beck Anksiyete Ölçeği
Received: 26.01 .2019

Accepted: 08.05.2019

Online First: 10.06 .2019

Corresponding Author: M. Kocak

ORCID: 0000-0003-0782-390X

Health Science University Fatih Sultan Mehmet Training and Research Hospital, Department of Emergency Medicine, Istanbul - Turkey

dr.mehmetkocak@gmail.com

O.A. Gul

ORCID: 0000-0001-7109-6108 Tekirdag State Hospital, Emergency Service, Tekirdag, Turkey

H. Aydin

ORCID: 0000-0003-3195-1805 Health Science University Bakirkoy Dr. Sadi Konuk Training and Research Hospital, Department of Emergency Medicine, Istanbul, Turkey

K. Aciksari

ORCID: 0000-0002-0749-4651

Istanbul Medeniyet University Faculty of Medicine, Department of Emergency Medicine, Istanbul, Turkey

D.N. Ozucelik ORCID: 0000-0002-7752-0667 Istanbul University Cerrahpasa

Faculty of Health Science, Department of Social Work, Istanbul, Turkey

(c) Copyright Istanbul Medeniyet University Faculty of Medicine. This journal is published by Logos Medical Publishing. Licenced by Creative Commons Attribution-NonCommercial 4.0 International (CC BY-NC 4.0) 


\section{INTRODUCTION}

Healthcare professionals, physicians in particular, are being exposed to various emotional and physical stressors in their working environments ${ }^{1}$. Changes in the organization, finance, and implementation of healthcare services day by day create new stressors besides offering new opportunities. Working environment poses psychosocial, ergonomic, and physicochemical threats for physicians. Moreover, violence and threat of violence to which physicians are exposed are the other growing occupational health problems ${ }^{2}$. Emergency departments in hospitals are further stressful working environments; burnout is high but job satisfaction is low among physicians working in emergency departments ${ }^{3}$. Dealing usually with patients having serious and life-threatening problems is a source of stress for emergency service physicians and this poses a risk for anxiety ${ }^{4}$.

It has been reported that the risk of various psychosocial problems such as stress, anxiety, depression, alcohol and drug abuse, and suicide are higher among physicians as compared with the normal population or other occupational fields ${ }^{3}$. Besides personal characteristics, many other factors concerning education and working conditions play a role in the development of such problems ${ }^{5}$. These factors include long working hours, excessive work load, lack of sleep, inadequate support mechanisms, exposure to infections or harmful substances, patient death, fear of malpractice, fear of being sued, bearing high responsibility, and negative relationships in working environment etc. Nevertheless, the rate of utilizing mental health services is low among physicians and medical students even though they are in need of help. The reasons for this unwillingness include being in the opinion that they can solve the problems on their own, having no time, and concern about the probability of breach of confidentiality and being recorded in the academic files ${ }^{6}$.

Anxiety disorders are among the most common mental disorders worldwide which are associated with many comorbidities. In population-based studies, the rate of lifetime occurrence of an anxiety disorder has been reported to reach 33.7 percent ${ }^{7}$. Studies from various countries have revealed that anxiety disorders are more common among physicians and medical students than in general population and are among the health problems with high priority ${ }^{8}$. Medical and mental health problems experienced by physicians are also of particular concern to public. Even very small mistakes that people dealing with human health can make while practicing their profession, may yield unfavorable outcomes. Therefore, keeping physicians' physical and mental health at the highest possible level is important. To achieve this goal, magnitude of the problem needs to be known and measures for preventable factors need to be taken. In the light of above-mentioned information, the present study aimed to determine the frequency of anxiety in emergency physicians and other medical specialists working in Turkey. In addition, the factors affecting anxiety were assessed and the effects of medical specialty were investigated.

\section{MATERIAL and METHODS}

This study approved by the Bakirkoy Dr. Sadi Konuk Education and Research Hospital Clinical Studies Ethical Committee (11 April 2016, 2016/03/27). Informed consent was taken from all participants.

This cross-sectional study targeted to reach all physicians working in hospitals under the umbrella of Ministry of Health in Turkey. A total of 6,913 individuals registered as a medical specialist in the electronic mail list of the Republic of Turkey Ministry of Health (eposta.saglik.gov.tr) were invited to the study via electronic mail. Only 542 (7.8\%) medical specialists accepted to participate in the study. Basic science specialists $(n=26)$ and the specialists with missing data in their questionnaire forms $(n=8)$ were excluded from the statistical analyses. Of 508 participants included in the 
analyses, 97 (19.1\%) were emergency physicians and 411 (80.9\%) were from other medical specialties.

After giving necessary explanations on the invitation electronic mail, the participants were asked to complete the questionnaire electronically. The questionnaire consisted of socio-demographic data form prepared by the researchers and the Beck Anxiety Inventory. The Beck Anxiety Questionnaire is a 21 -item, self-report scale and each item is rated on a 4-point scale between 0 (not at all) and 3 (severe-I could barely stand it). The validity and reliability study of the Turkish version of the scale was performed by Ulusoy et al. ${ }^{10}$. In the present study, Beck anxiety score of 0-9 was considered as no/minimal anxiety, 10-16 mild anxiety, 17-29 moderate anxiety, and 3063 severe anxiety. The characteristics of anxiety groups, which were established according to the Beck anxiety scores were compared. Besides, the frequency of anxiety and other characteristics of the participants were investigated according to their medical specialties (emergency medicine and other).

\section{Statistical Analysis}

Data analysis was performed using the IBM SPSS Statistics for Windows version 23 (IBM Corp., Armonk, NY, USA). Descriptive statistics were expressed as numbers and percentages for categorical variables and as mean and standard deviation (SD) for numerical variables. Chi-square test was used to compare independent categorical variables, whereas comparison of numerical variables between the groups was performed using t-test in case the condition for normal distribution was provided, otherwise Mann-Whitney $U$ test was used. The relationship between numerical variables was identified using Spearman's rho test. The results were evaluated within confidence intervals of $95 \%$ and $99 \%$ and at a level of statistical significance of $\mathrm{p}<0.05$ and $\mathrm{p}<0.01$.

\section{RESULTS}

A total of 542 medical specialists completed the questionnaires. Basic science specialists $(n=26)$ and the specialists with missing data in their questionnaire forms $(n=8)$ were excluded from the statistical analyses. Of 508 medical specialists included in the analyses, $143(28.1 \%)$ were female and 365 (71.9\%) were male; their mean age was $37.5 \pm 7.2$ years (mean ages of male, and female physicians were $38,6 \pm 7.7$, and $35.8 \pm 5.3$ years, respectively ). The sociodemographic characteristics of the participants are demonstrated in Table 1.

Table 1. Sociodemographic characteristics of the participants.

\begin{tabular}{ll}
\hline Characteristics & Mean \pm SD \\
\hline Age, year & $37.5 \pm 7.2$ \\
& $\mathrm{n}(\%)$ \\
Gender & $143(28.1)$ \\
$\quad$ Female & $365(71.9)$ \\
$\quad$ Male & \\
Marital status & $406(79.9)$ \\
$\quad$ Married & $77(15.2)$ \\
$\quad$ Single & $25(4.9)$ \\
$\quad$ Divorced & $148(29.1)$ \\
Smoking & $165(32.5)$ \\
Alcohol consumption & $92(18.1)$ \\
History of a chronic disease & $110(21.7)$ \\
History of regular drug use & $71(14.0)$ \\
Family history of a psychiatric disorder & $282(55.5)$ \\
Duration of working as a specialist $<5$ years & $47.1 \pm 11.2$ \\
Weekly working hours & \\
Medical specialty & $97(19.1)$ \\
$\quad$ Emergency medicine & $82(16.1)$ \\
$\quad$ Internal medicine/pediatrics & $95(18.7)$ \\
$\quad$ General surgery/orthopedics & $127(25.0)$ \\
Other internal medical specialties & $107(21.1)$ \\
Other surgical medical specialties &
\end{tabular}

Data are presented as mean \pm standard deviation and number (\%), where appropriate.

The Beck anxiety scores of the participants ranged from 0 to 45 (mean, 9.6 \pm 7.7 ) points. Participants had no/minimal $(n=296$ (58.3\%), mild $(n=128$ : $25.2 \%)$, moderate $(n=70: 13.8 \%)$, and severe $(\mathrm{n}=14: 2.8 \%)$ anxiety (Figure 1). The percentage of those with moderate-severe anxiety was $16.5 \%$.

The characteristics of participants according to the level of anxiety are demonstrated in Table 2 . The- 


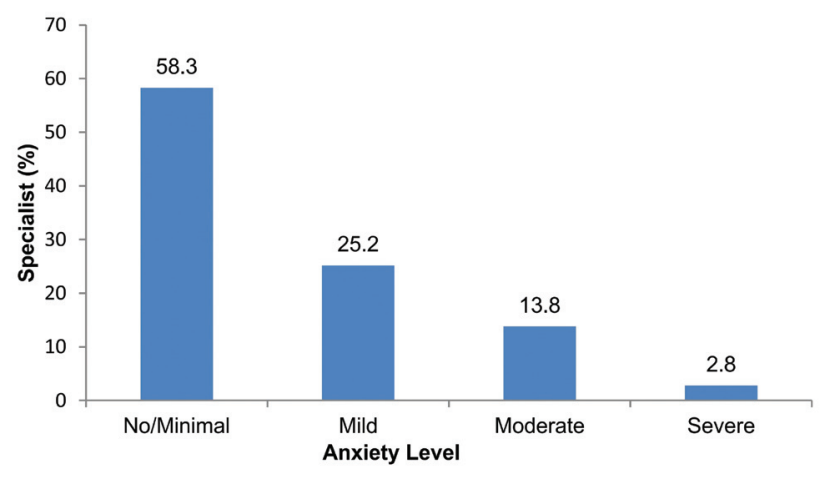

Figure 1. Distribution of the participants according to their anxiety levels.

re were significant differences among the anxiety groups in terms of gender, smoking, family history of a psychiatric disorder, and medical specialty. While the frequency of moderate-severe anxiety was $26.6 \%$ among female, and $12.6 \%$ among male specialists $(p<0.001)$. The rates of smoking and having a family history of a psychiatric disorder were higher in those with moderate anxiety as compared with the other groups $(p<0.001$ and $p=0.001$, respectively). While the frequency of moderate-severe anxiety was 33\% in the emergency physicians, and $12.7 \%$ in the other medical specialists $(p<0.001)$.
Table 3. Correlation of anxiety score with age, duration of working as a specialist, and weekly working hours.

\begin{tabular}{lll}
\hline & rho & p \\
\hline Age, year & -0.168 & $<0.001$ \\
Duration of working as a specialist, year & -0.217 & $<0.001$ \\
Weekly working hours & 0.043 & 0.330
\end{tabular}

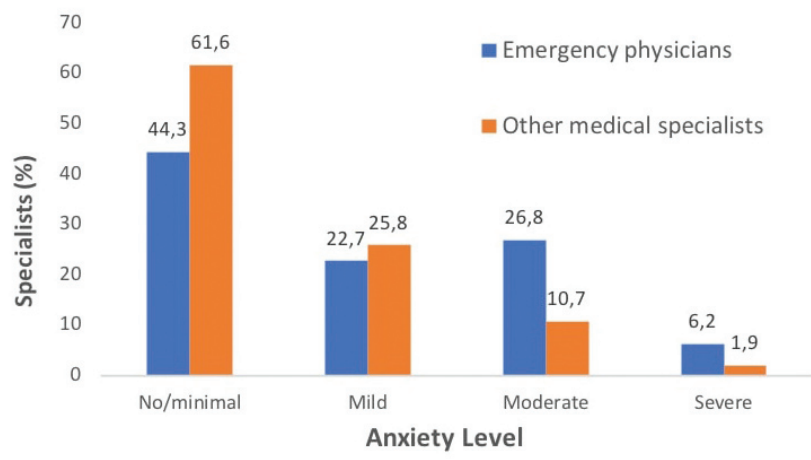

Figure 2. Distribution of anxiety levels according to the medical specialties.

Anxiety score showed a weak but significant negative correlation with age and years of service as a specialist (rho:-0.168 and -0.217; $\mathrm{p}<0.001$, respectively). No significant correlation was found between weekly working hours and anxiety scores $(p=0.330)$ (Table 3$)$.

Table 2. Characteristics of the medical specialists according to the level of anxiety.

\begin{tabular}{|c|c|c|c|c|c|}
\hline & \multicolumn{4}{|c|}{ Level of Anxiety } & \multirow[b]{2}{*}{$\mathbf{p}$} \\
\hline & $\begin{array}{c}\text { No/Minimal } \\
(\mathbf{n}=\mathbf{2 9 6}) \\
\text { n (\%) }\end{array}$ & $\begin{array}{l}\text { Mild } \\
(\mathbf{n}=\mathbf{1 2 8}) \\
\mathrm{n}(\%)\end{array}$ & $\begin{array}{l}\text { Moderate } \\
(\mathbf{n}=70) \\
\text { n }(\%)\end{array}$ & $\begin{array}{l}\text { Severe } \\
(n=14) \\
n(\%)\end{array}$ & \\
\hline \multicolumn{6}{|l|}{ Gender } \\
\hline Female $(n=143)$ & $62(43.4)$ & $43(30.1)$ & $35(24.5)$ & $3(2.1)$ & $<0.001$ \\
\hline Male $(n=365)$ & $234(64.1)$ & $85(23.3)$ & $35(9.6)$ & $11(3.0)$ & \\
\hline \multicolumn{6}{|l|}{ Marital status } \\
\hline Single $(n=77)$ & $39(50.6)$ & $21(27.3)$ & $16(20.8)$ & $1(1.3)$ & 0.444 \\
\hline Married $(n=406)$ & $244(60.1)$ & $103(25.4)$ & $48(11.8)$ & $11(2.7)$ & \\
\hline Divorced $(n=25)$ & $13(52.0)$ & $4(16.0)$ & $6(24.0)$ & $2(8.0)$ & \\
\hline Smoking & $69(23.3)$ & $41(32.0)$ & $34(48.6)$ & $4(28.6)$ & $<0.001$ \\
\hline Alcohol consumption & $84(28.4)$ & $50(39.1)$ & $26(37.1)$ & $5(35.7)$ & 0.135 \\
\hline History of chronic disease & $50(16.9)$ & $24(18.8)$ & $14(20.0)$ & $4(28.6)$ & 0.675 \\
\hline History of regular drug use & $65(22.0)$ & $23(18.0)$ & $17(24.3)$ & $5(35.7)$ & 0.397 \\
\hline Family history of a psychiatric disorder & $27(9.1)$ & $23(18.0)$ & $18(25.7)$ & $3(21.4)$ & 0.001 \\
\hline \multicolumn{6}{|l|}{ Medical specialty } \\
\hline Emergency medicine $(n=97)$ & $43(44.3)$ & $22(22.7)$ & $26(26.8)$ & $6(6.2)$ & $<0.001$ \\
\hline Other $(n=411)$ & $253(61.6)$ & $106(25.8)$ & $44(10.7)$ & $8(1.9)$ & \\
\hline
\end{tabular}


There was a significant difference between the emergency physicians and the other medical specialists in terms of their distribution according to the anxiety groups $(p<0.001)$ (Figure 2$)$.

Comparison of the characteristics of emergency physicians and other medical specialists revealed that the rates of smoking $(p=0.008)$ and alcohol consumption $(p=0.003)$ were higher, duration of working as a specialist $(p<0.001)$ was shorter, and the mean anxiety score was higher in the emergency physicians $(p<0.001)$ (Table 4$)$.

Table 4. Comparison of the characteristics of emergency physicians and other medical specialists.

\begin{tabular}{|c|c|c|c|}
\hline & \multicolumn{3}{|c|}{ Medical specialty } \\
\hline & $\begin{array}{l}\text { Emergency } \\
\text { medicine } \\
(\mathrm{n}=97)\end{array}$ & $\begin{array}{l}\text { Other } \\
(n=411)\end{array}$ & $\mathbf{p}$ \\
\hline Age, year & $35.5 \pm 5.0$ & $38.0 \pm 7.6$ & 0.051 \\
\hline \multicolumn{4}{|l|}{ Gender } \\
\hline Female & 30 (30.9) & $113(27.5)$ & 0.499 \\
\hline Male & $67(69.1)$ & $298(72.5)$ & \\
\hline \multicolumn{4}{|l|}{ Marital status } \\
\hline Single & $16(16.5)$ & $61(14.8)$ & 0.444 \\
\hline Married & $74(76.3)$ & $332(80.8)$ & \\
\hline Divorced & $7(7.2)$ & $18(4.4)$ & \\
\hline Smoking & $39(40.2)$ & $109(26.5)$ & 0.008 \\
\hline Alcohol consumption & $44(45.4)$ & $121(29.4)$ & 0.003 \\
\hline History of a chronic disease & $18(18.6)$ & $74(18.0)$ & 0.899 \\
\hline History of regular drug use & $14(14.4)$ & 57 (13.9) & 0.885 \\
\hline $\begin{array}{l}\text { Family history of a } \\
\text { psychiatric disorder }\end{array}$ & $23(23.7)$ & $87(21.2)$ & 0.584 \\
\hline \multicolumn{4}{|l|}{ Duration of working } \\
\hline$<5$ & $76(78.4)$ & $206(50.1)$ & $<0.001$ \\
\hline $5-9$ & $17(17.5)$ & $91(22.1)$ & \\
\hline $10-14$ & $2(2.1)$ & 45 (10.9) & \\
\hline $15-19$ & $0(0.0)$ & $37(9.0)$ & \\
\hline $20-24$ & $1(1.0)$ & $13(3.2)$ & \\
\hline$>25$ & $1(1.0)$ & $19(4.6)$ & \\
\hline Weekly working hours & $46.9 \pm 8.5$ & $47.2 \pm 11.8$ & 0.077 \\
\hline Beck anxiety score & $13 \pm 9.3$ & $8.7 \pm 7.0$ & $<0.001$ \\
\hline
\end{tabular}

Data are presented as mean \pm standard deviation or number (\%), where appropriate.

\section{DISCUSSION}

Anxiety disorders are among the most common mental disorders. One-month prevalence of anxiety disorders in general population has been re- ported to be $7 \%{ }^{11}$. Besides, their reported annual prevalence rates range from $6 \%$ to $20 \%$, whereas lifetime prevalence has been reported to be between $14 \%$ and $34 \%^{7}$. In the studies on different groups of physicians, reported prevalence of anxiety disorders ranges from $15 \%$ to 29 percent ${ }^{12-}$ 15. In the present cross-sectional study, the rate of moderate-severe anxiety among the medical specialists was $16.5 \%$ and the mean Beck anxiety score was 9.6 \pm 7.7. A study from Pakistan reported a mean Beck anxiety score of 8.05 for physicians ${ }^{8}$. In a single-center study from Turkey, the mean Beck anxiety score was found to be $8.7 \pm 8.2^{13}$.

Sociodemographic characteristics are likely to have an impact on anxiety levels. In general population, anxiety is usually more prevalent in females than in males ${ }^{16}$. Likewise, it has been reported that female physicians have higher anxiety levels than male physicians ${ }^{12,17}$. In addition to the constraints imposed on all physicians, female physicians are also exposed to specific stressors related to discrimination, lack of role model and support, role stress, and overload. In academic field, women get a promotion more slowly, are paid less, benefit from fewer resources, and suffer from a number of micro-inequalities ${ }^{17}$. In the present study, there was a significant difference between male and female physicians in terms of anxiety levels $(p<0.001)$. While the frequency of moderate-severe anxiety was $26.6 \%$ in female physicians, it was $12.6 \%$ in males. Despite all difficulties, female physicians are usually satisfied with their career and cope with stressors owing to their personal coping techniques ${ }^{17}$. It has been reported that anxiety is more prevalent in young and middle-aged adults (25-44 years of age); however, its prevalence is low in advanced ages (>65 years) in general population ${ }^{11}$. Similarly, the present study determined a negative correlation between the physicians' age and anxiety levels (rho $=-0.168, p<0.001)$. It has been reported that in general population anxiety is more common among separated, divorced, and widowed individuals as compared with those married ${ }^{11,16}$. In 
the present study, no significant correlation was determined between anxiety levels and marital status. Nevertheless, it was determined that the frequency of moderate-severe anxiety was higher in the divorced physicians (32\%) than in the single $(22.1 \%)$ and married (14.5\%) physicians.

Alcohol consumption and smoking are also among the factors investigated for their relationship with anxiety. A relationship has been reported between alcohol consumption and anxiety ${ }^{16}$. In the present study, there was no significant correlation between alcohol consumption and anxiety in all participants. However, when evaluated according to the medical specialties, frequency of alcohol consumption, and also level of anxiety were found to be higher among the emergency physicians, when compared with the physicians from other medical specialties $(45.4 \%$ vs. $29.4 \%$; $\mathrm{p}=0.003)$. Smoking is one of the factors associated with anxiety in general population ${ }^{16}$. It has been demonstrated that anxiety scores are higher in current smokers than in ex-smokers. An association has been also reported between smoking and anxiety in physicians ${ }^{14}$. In the present study, the rate of smoking was the highest (48.6\%) in the physicians with moderate anxiety, whereas it was the lowest (28.4\%) in those without anxiety. Moreover, smoking was found to be more prevalent in the emergency physicians, who had higher anxiety, as compared with the physicians from other medical specialties ( $40.2 \%$ vs. $26.5 \%$; $p=0.008$ ).

Working environment and occupational risks might have a role in developing anxiety. Long working hours (>60 hours/week) have been reported to be associated with the symptoms of depression and anxiety ${ }^{14}$. In the present study, the mean weekly working hours of the physicians was $47.1 \pm 11.2$ hours and no significant correlation was determined between weekly working hours and anxiety scores. There are studies reporting that the physicians' occupational experience gained in years favorably contributes to job satisfaction, which is considered a protective factor against stress and psychological disorders ${ }^{4}$. Likewise, in the present study, a negative correlation was determined between duration of working as a specialist and anxiety score (rho=-0.217, $\mathrm{p}<0.001)$.

In the literature, studies investigating the physicians' levels of anxiety according to their medical specialties are limited in number. In a study evaluating the relationship between the medical specialties and stress among physicians, with regard to their choice of career, laboratory-based physicians were found to be the most unhappy and stressful, whereas surgeons were found to be the happiest and least stressful. It has been reported that suicide attempt is more common among psychiatrists as compared with the other medical specialties $^{18}$. Anesthesiologists have been reported to be at high risk for anxiety and depression due to night shifts and long working hours. Moreover, substance use has been reported to be higher in emergency physicians and psychiatrists among physicians ${ }^{19}$. Emergency service physicians are exposed to numerous occupational dangers, which include infectious diseases, latex allergy, exposure to nitrous oxide, working in shifts, exposure to violence, and emotional stress ${ }^{20}$. Exposure to verbal or physical assault is quite common in emergency service workers ${ }^{21}$. In addition, burnout has been reported as a frequent problem seen in emergency service physicians ${ }^{22}$. A direct correlation has been demonstrated between burnout and exposure to assault in emergency service physicians ${ }^{21}$. In general, burnout has been found to be strongly associated with anxiety disorders ${ }^{23}$. Studies have revealed that high level of stress, burnout or depression in physicians emergency physicians still persist even they stop working in this field ${ }^{24}$.

In the present study, the frequency of moderatesevere anxiety was higher in the emergency physicians as compared with the physicians of other medical specialties (33\% vs. $12.7 \%$ ). Comparing the emergency physicians with the other medical specialists, it was observed that the rate 
of smoking and alcohol consumption was higher in the emergency physicians and they were working as a specialist for shorter time. There was no difference between the two groups of physicians in terms of age, gender, marital status, history of a chronic disease, history of regular drug use, family history of a psychiatric disorder, and weekly working hours.

Earlier studies have revealed that physicians usually hesitate consulting another physician when they get sick or suffer from psychological distress and prefer self-medication ${ }^{25-27}$. Particularly, physicians with psychological or mental problem ignore their problem or try to cope with the problem using their personal methods deeming it unnecessary to receive professional help or they get used to living with such kind of problems ${ }^{28,29}$. The reasons for physicians' not seeking for professional help for their mental problems include the fear that their occupational career would be affected ${ }^{30}$. Such an attitude of physicians might keep them from receiving appropriate health care. Since physicians' mental health is a public health problem, it is inevitable to develop measures for reducing the incidence of psychiatric disorders and for prevention, recognition, and treatment of such disorders in physicians. Physicians who have such kind of disorders may deal poorly with their patients and may cause problems with their co-workers in the workplace. The majority of studies conducted to assess psychological status of physicians are selfreported surveys measuring anxiety, depression, and sleep problems instead of taking the diagnosis of a psychiatrist into consideration. Besides, sample size in these studies is limited. Studies should focus on the actual risk of such psychiatric problems in physicians. In addition to earlier studies, it is required not only to conduct studies investigating in detail the factors that influence the physicians' health, such as substance abuse, but also to establish methods for reducing stress and burnout. Moreover, it is also required to investigate the factors not allowing physicians to reach psychiatry resources as well as to take measures.
In the present study, only $7.8 \%$ of the medical specialists accepted to participate in the study.

This low response rate can be considered one of the limitations of the study. Moreover, the study being a questionnaire study and based on selfreported data can be accepted as other limitations.

This survey was completed in response to an open invitation; thereof, it might have been completed mainly by physicians who had dissatisfied of their jobs and thus are more sensitive on this issue. The most important limitation of our study is the fact that our survey was designed online and the volunteers were invited via electronic mails. We believe that our data would be different if they were collected by face to face interviews.

\section{CONCLUSIONS}

The incidence of anxiety is high among medical specialists. Considering the specialties, higher anxiety level is seen in emergency physicians. Given that the physicians deal with human health, this can be considered a significant public health problem and thus physical and mental health of the physicians should be kept at the highest possible level. The fact that physicians hesitate seeking professional help for their own problems should also be taken into account and strategies need to be developed to investigate the working conditions as well as to establish protective and preventive policies.

\section{References}

1. Department of Health and Human Services. Exposure to stress. In: Occupational hazards in hospitals. Centers for Disease Control and Prevention, National Institute for Occupational Safety and Health 2008. https://www.cdc. gov/niosh/docs/2008-136/pdfs/2008-136.pdf. Accessed 17 May 2018.

2. Arnetz BB. Psychosocial challenges facing physicians of today. Soc Sci Med. 2001;52:203-13. [CrossRef]

3. Xiao Y, Wang J, Chen S, et al. Psychological distress, burnout level and job satisfaction in emergency medicine: A cross-sectional study of physicians in China. Emerg Med 
Australas 2014;26:538-42. [CrossRef]

4. Dias RD, Scalabrini Neto A. Acute stress in residents during emergency care: a study of personal and situational factors. Stress. 2017;20:241-8. [CrossRef]

5. Tyssen R, Vaglum P. Mental health problems among young doctors: an updated review of prospective studies. Harv Rev Psychiatry 2002;10:154-65. [CrossRef]

6. Center C, Davis M, Detre T, et al. Confronting depression and suicide in physicians: a consensus statement. JAMA 2003;289:3161-6. [CrossRef]

7. Bandelow B, Michaelis S. Epidemiology of anxiety disorders in the $21^{\text {st }}$ century. Dialogues Clin Neurosci 2015; 17:327-35.

8. Khuwaja AK, Qureshi R, Azam SI. Prevalence and factors associated with anxiety and depression among family practitioners in Karachi, Pakistan. J Pak Med Assoc. 2004;54:45-9.

9. Beck AT, Epstein N, Brown G, et al. An inventory for measuring clinical anxiety: psychometric properties. J Consult Clin Psychol. 1988;56:893-7. [CrossRef]

10. Ulusoy $M$, Sahin $N H$, Erkmen $H$. Turkish version of the Beck Anxiety Inventory. J Cogn Psychother 1998;12:16372.

11. Martin P. The epidemiology of anxiety disorders: A review. Dialogues Clin Neurosci. 2003;5:281-98. [CrossRef]

12. Erdur B, Ergin A, Turkcuer I, et al. A study of depression and anxiety among doctors working in emergency units in Denizli, Turkey. Emerg Med J. 2006;23:759-63. [CrossRef]

13. Shen LL, Lao LM, Jiang SF, et al. A survey of anxiety and depression symptoms among primary-care physicians in China. Int J Psychiatry Med. 2012;44:257-70. [CrossRef]

14. Gong Y, Han T, Chen W, et al. Prevalence of anxiety and depressive symptoms and related risk factors among physicians in China: a cross-sectional study. PLoS One. 2014;9:e103242. [CrossRef]

15. Pougnet R, Di Costanzo LP, Kerrien M, et al. Occupational factors for mood and anxiety disorders among junior medical doctors. Med Lav. 2015;106:386-93.

16. McEvoy PM, Grove R, Slade T. Epidemiology of anxiety disorders in the Australian general population: findings of the 2007 Australian National Survey of Mental Health and Wellbeing. Aust N Z J Psychiatry 2011;45:957-67. [CrossRef]

17. Robinson GE. Stresses on women physicians: consequences and coping techniques. Depress Anxiety 2003;17:180-9. [CrossRef]
18. Chagas MHN, Barros HTT, da Costa RFA. The choice of psychiatry as a specialty: why do we need to pay attention? Arch Clin Psychiatry 2016;43:18-9. [CrossRef]

19. Hughes PH, Baldwin DC, Sheehan DV, et al. Resident physician substance use, by specialty. Am J Psychiatry 1992;149:1348-54. [CrossRef]

20. Dorevitch S, Forst L. The occupational hazards of emergency physicians. Am J Emerg Med. 2000;18:300-11. [CrossRef]

21. Erdur B, Ergin A, Yüksel A, et al. Assessment of the relation of violence and burnout among physicians working in the emergency departments in Turkey. Ulus Travma Acil Cerrahi Derg. 2015;21:175-81. [CrossRef]

22. Bragard I, Dupuis G, Fleet R. Quality of work life, burnout, and stress in emergency department physicians: a qualitative review. Eur J Emerg Med. 2015;22:227-34. [CrossRef]

23. Sun W, Fu J, Chang Y, Wang L. Epidemiological study on risk factors for anxiety disorder among Chinese doctors. J Occup Health 2012;54:1-8. [CrossRef]

24. Doan-Wiggins L, Zun L, Cooper MA, et al. Practice satisfaction, occupational stress, and attrition of emergency physicians. Wellness Task Force, Illinois College of Emergency Physicians. Acad Emerg Med. 1995;2:556-63. [CrossRef]

25. Fridner A, Belkic K, Marini M, et al. Why don't academic physicians seek needed professional help for psychological distress? Swiss Med Wkly. 2012;142:w13626. [CrossRef]

26. Rosvold EO, Bjertness E. Illness behaviour among Norwegian physicians. Scand J Public Health 2002;30:12532. [CrossRef]

27. TYSSEN R. Health Problems and the Use of Health Services among Physicians: A Review Article with Particular Emphasis on Norwegian Studies. Ind Health 2007;45:599610. [CrossRef]

28. Edwards N, Kornacki MJ, Silversin J. Unhappy doctors: what are the causes and what can be done? BMJ 2002;324:835-8. [CrossRef]

29. Tyssen R, Røvik JO, Vaglum P, et al. Help-seeking for mental health problems among young physicians: Is it the most ill that seeks help? A longitudinal and nationwide study. Soc Psychiatry Psychiatr Epidemiol. 2004;39:98993. [CrossRef]

30. Hassan TM, Ahmed SO, White AC, et al. A postal survey of doctors' attitudes to becoming mentally ill. Clin Med (Lond) 2009;9:327-32. [CrossRef] 